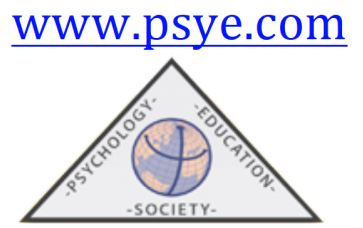

\title{
Teaching Autonomy: Does Spanish Education System Achieve the Desired Effect?
}

\author{
Rolando ANGEL-ALVARADO ${ }^{1}$, Miguel R. WILHELMI ${ }^{2} \&$ Olga BELLETICH $^{2}$ \\ ${ }^{1}$ Instituto de Música. Universidad Alberto Hurtado (Chile) \\ ${ }^{2}$ Facultad de Ciencias Humanas y Sociales. Universidad Pública de Navarra (España)
}

(Received on June 9th, 2019; Accepted on October 25th, 2019)

\begin{abstract}
Despite the Spanish curriculum for primary education establishes compulsory and elective subjects in order to promote teacher autonomy; curricular management is achieving the opposite of the desired effect according to teachers. This study aims statistically comparing the autonomy of educators who teach compulsory subjects and who only impart elective subjects. The method comprises a nonexperimental quantitative research design, establishing a random cluster sampling that has statistical representativeness from national standpoint. Results demonstrate that teachers who only impart elective subjects perceive a greater enjoyment toward pedagogical activity than the other group. In conclusion, it is reasonable to put the Spanish curriculum under scrutiny because its effectiveness for fostering the teacher autonomy is questioned.
\end{abstract}

Keywords: autonomous motivation, teacher behaviour, job satisfaction, basic psychological needs, selfdetermination theory

Autonomía docente: ¿Logra el sistema educativo español el efecto deseado?

RESUMEN: A pesar de que el currículo español para la educación primaria establece asignaturas troncales y específicas para promover la autonomía docente, la gestión curricular está logrando el efecto contrario según el profesorado. El objetivo de este estudio es comparar estadísticamente la autonomía de maestras y maestros que imparten asignaturas troncales y de quienes enseñan solo asignaturas específicas. El método comprende un diseño cuantitativo no experimental, estableciendo una muestra aleatoria estratificada que tiene representatividad nacional. Los resultados demuestran que el profesorado que solo imparte asignaturas específicas percibe mayor satisfacción hacia la actividad pedagógica que el otro grupo. En conclusión, es razonable poner bajo escrutinio el currículo español porque su efectividad para fomentar la autonomía docente queda cuestionada.

Palabras clave: motivación autónoma, comportamiento del profesorado, satisfacción laboral, necesidades psicológicas básicas, teoría de la autodeterminación

Correspondencia: Rolando Angel-Alvarado. Instituto de Música. Universidad Alberto Hurtado. CP: 8340540 Santiago de Chile. E-mail: rolando.angel.alvarado@gmail.com 


\section{Introducción}

The Spanish education policy -the Organic Law for the Improvement of Education Quality (LOMCE, which is the acronym in Spanish)- was enacted in order to provide more teacher autonomy (MECD, 2013). However, the scientific assumption is that LOMCE achieves the opposite of the desired effect (Gairín, 2015; Prieto \& Villamor, 2018; Sacristán, 2014) because the curricular management is limiting the capacity for making pedagogical decisions.

Self-Determination Theory (SDT) allows understanding this social tension as the autonomy is essential for the promotion of autonomous motivation (Reeve, Ryan, \& Deci, 2019; Van den Broeck, Vansteenkiste, De Witte, Soenens, \& Lens, 2010). Specifically, autonomous motivation is understood as a sense of will when making decisions during an activity (Ryan \& Deci, 2017), given that individuals display high degrees of intrinsic motivation and identified regulation (Riley, 2016). Therefore, the autonomous motivation entails a degree of autonomy to the moment of making decisions, as those actions are based on the pleasure that the activity gives to an individual (Deci \& Ryan, 2000). For that reason, autonomous motivation may be promoted or discouraged by environmental factors (Ryan \& Deci, 2000; Vansteenkiste \& Ryan, 2013) that have an impact on the mental health of individuals.

The present study proposes to establish statistical differences in the autonomous motivation between educators who teach compulsory subjects and who only impart elective subjects in primary education schools, applying procedures linked to effect size for nonparametric tests and bivariate correlations of Pearson. Given that the satisfaction of the need for autonomy plays a determinant role in the autonomous motivation (Ryan \& Deci, 2017), the research hypothesis postulates that there is a statistically significant difference between both groups in need for autonomy.

\section{A Mini-Theory from SDT: Basic Psychological Needs Theory}

SDT postulates the Basic Psychological Needs Theory, which is made up of three basic or innate psychological needs (Ryan \& Deci, 2019) because it focuses on the existent relationships between environmental conditions and the mental health of the individual (Gunnell, Crocker, Wilson, Mack, \& Zumbo, 2013). These basic psychological needs must be satisfied in order to encourage selfdetermined behaviour (Gagné, 2009), having then an impact on autonomous motivation (Deci \& Ryan, 2000). Specifically, the need for autonomy entails the desire for choice as well as a feeling of willpower during an activity. Secondly, the need for competence implies the desire for optimal performance within the workplace with the intention of achieving goals. Lastly, the third basic psychological need is relatedness, which involves interpersonal knowledge through the social interaction between members of an institution. It is important to consider that, whereas the satisfaction of these basic psychological needs "contributes to proactivity, integration, and wellbeing, the frustration of these same psychological needs..., leaves one prone to passivity, fragmentation, and ill-being" (Vansteenkiste \& Ryan, 2013, p. 263).

In manufacturing productive enterprises, needs for competence and relatedness are recognisable since the former is related to technical abilities while the latter is linked with social skills (Deci et 
al., 2001). Therefore, in this study that is only interested in the teacher's motivation, the pedagogical knowledge is linked with the need for competence as it is applied in front of students during the lesson, whereas the sense of relatedness is satisfied by the school community.

The proposed viewpoint in this research is not innovative because some previous studies have analysed innate psychological needs from the perspective of teaching tasks. More specifically, Korthagen and Evelein (2016) reported that satisfaction of the need for competence strengthens the structure in the classroom as it is associated with the teacher's leadership behaviour. These authors also found that satisfaction of the need for relatedness creates a collaborative relationship between teachers and students. Along the same lines, Klassen, Perry, and Frenzel (2012) have stated that teachers' satisfaction of the need for relatedness leads to higher levels of engagement and positive emotions with students more than colleagues. Regarding the need for autonomy, three studies have reported that its satisfaction reduces the effects of control, thus improving students' perception of freedom (Korthagen \& Evelein, 2016; Marshik, Ashton, \& Algina, 2017; Pelletier, SéguinLévesque, \& Legault, 2002). Therefore, the need for autonomy plays a decisive role in establishing the pedagogical authority and classroom management (Deci \& Ryan, 2016; Reeve et al., 2019).

\section{Spanish Education Policy: Lomce}

It establishes three frameworks of subjects for primary education. The first framework is integrated by subjects that are assessed through standardised tests, such as natural sciences, social sciences, language, maths, and foreign language. These areas are measured through the Programme for International Student Assessment (PISA) and the European Survey on Language Competences (ESLC). The second framework encompasses a variety of subjects, where physical education is a mandatory discipline, and the rest of the knowledge areas are considered elective subjects. In this regard, parents and guardians choose one subject between religion and social \& civic values, as well as select at least one discipline between arts education and second foreign language. Finally, LOMCE stipulates the third framework of elective subjects with the intention of providing a certain degree of curricular freedom to address issues of local interest in autonomous communities. According to our data, there are a wide variety of subjects for imparting, such as reading circles, therapeutic pedagogy, computer courses, philosophy, handicrafts, in addition to local languages.

\section{Method}

This cross-sectional study is carried out by using a nonexperimental quantitative research approach. Therefore, no variable is controlled during the procedures of data collection and analysis.

\section{Sample}

Participants work as teachers in primary schools situated in Aragon, Balearic Islands, Basque Country, Castile and Leon, Madrid and Navarre because those autonomous communities have formally published full primary school lists, providing relevant institutional information such as a postal address, e-mail, telephone number, and so on. Therefore, all teachers had the same participation opportunity, such that random cluster sampling is constituted. The sample is 
considered as probability sampling (Mertler, 2016), making it feasible to carry out a variety of statistical techniques in order to establish the sample size.

Based on the updated official statistics from the Spanish Government, the sample size has statistical representativeness because more than 655 primary education teachers have participated in this research. The sample size was calculated in conformity with three quantitative conditions (Hair, Wolfinbarger, Money, Samouel, \& Page, 2015): a confidence level of $99 \%(d=.01$, or significance level for establishing type I error), a margin of error of $5 \%$, and a proportion equivalent to $50 \%$. The total sample $(n=730)$ was divided into two conglomerates. The first conglomerate is made up of educators who teach compulsory subjects in primary schools $(n=$ 611), while the second group incorporates all teachers who only impart elective subjects at schools $(n=119)$, that is to say, teachers who impart subjects classified in the second or third frameworks stipulated by LOMCE.

\section{Measures}

Teacher motivation. The Work Tasks Motivation Scale for Teachers (WTMST; Fernet, Senécal, Guay, Marsh, \& Dowson, 2008) was translated into the Spanish language by Ruiz (2015). The measure consists of six items that are distributed in two subscales: intrinsic motivation (three items; e.g., because it is pleasant to carry out this task) and identified regulation (three items; e.g., because I find this task important for the academic success of my students). All items were rated on a 7point Likert scale ranging from 1 (does not correspond at all) to 7 (absolutely correspond). In this study, the WTMST Spanish version indicated, considering only the concerned subscales, a Cronbach Alpha coefficient of .80, which is acceptable (Clayson, 2017). The observed goodness of fit indices were also acceptable $\left(\mathrm{f}^{2}=33.42 ; \mathrm{df}=8 ; \mathrm{NFI}=.98 ; \mathrm{TLI}=.97 ; \mathrm{CFI}=.98\right)$, although the close fit $(p$-close $=.1)$ in default model of RMSEA was equal to .06 and $90 \% \mathrm{CI}$ ranging from .04 to .09 (Aldous, 2019).

Teacher's basic psychological needs. The Basic Psychological Needs Scale for Teachers (BPNS-T; Angel-Alvarado, Wilhelmi, \& Belletich, in press) consists of seven items that are distributed in three subscales: autonomy (two items; e.g., I feel at liberty to teach in the way I consider most appropriate), competence (three items; e.g., my students value and appreciate me), and relatedness (two items, e.g., when I share with people in my working environment, I trust them). All indicators were rated on a 5-point Likert scale ranging from 1 (does not correspond at all) to 5 (absolutely correspond). In this study, the BPNS-T indicated a Cronbach Alpha coefficient of .78, which is acceptable (Clayson, 2017). The goodness of fit indices were also acceptable $\left(f^{2}=47.32 ; \mathrm{df}=11\right.$; $\mathrm{NFI}=.98 ; \mathrm{TLI}=.96 ; \mathrm{CFI}=.98)$, highlighting the close fit $(p$-close $=.06)$ in RMSEA as default model was equal to .06 and $90 \%$ CI ranging from .04 to .08 (Aldous, 2019).

\section{Data collection procedures}

In conformity with the Spanish data protection regulation, researchers requested school administrations share the access link, which was attached to an e-mail, with the teaching staff. Through Google Forms, educators read the conditions of participation, instructions, and the confidentiality agreement as part of the ethical protocol established for conducting the research 
activity, taking the Ethics for Researchers promoted by European Union (2013) as a normative guideline. Therefore, all participant teachers applied both measures by their own accord, voluntarily gave some contact information, and were considered competent in applying both measures as they work as teachers in primary schools. The scales' proportionality also was ensured because, in addition to items referred to motivation and innate psychological needs, only basic demographic information was requested in both scales. Finally, it is important to highlight that most of the participant teachers positively appraised the importance of this study.

\section{Data analysis procedures}

Using SPSS, both conglomerates of teachers were contrasted regarding motivational categories and three basic psychological needs. First of all, both groups were analysed through the KolmogorovSmirnov Test in order to establish whether each sample displays a normal distribution. Subsequently, those clusters were compared through Levene's Test and one-way ANOVA as the former procedure verifies the homogeneity of variance, while the second procedure is useful for observing whether there is mean equality or not between both sampling units. All these tests consider the established significance level $(d=.01)$ in order to determine if differences in alternative hypotheses are accepted or rejected.

Secondly, both scales provide ordinal data, which are described using percentages (Hinton, 2014). Therefore, it is convenient to carry out a nonparametric alternative for comparing both conglomerates, especially in the case that normal distribution is not observed. Specifically, the Mann-Whitney U Test allows analysing statistically significant differences between the two groups (Rosenthal, 2012). It also enables to observe eta squared $\left(\eta^{2}\right)$ as a measure of effect size when the $z$ value is elevated to the second power and divided by the sample size (Fritz, Morris, \& Richler, 2012). It is undeniable that partial eta squared $\left(\eta_{p}^{2}\right)$ is the most common effect size reported in educational research (Field, 2017; Fritz et al., 2012; Norouzian \& Plonsky, 2018; Richardson, 2011). However, the present study will utilise $\eta^{2}$ because it "is the differentiation ratio. It measures the proportion of the variation in $\mathrm{Y}$ that is associated with membership of the different groups defined by X" (Richardson, 2011, p. 136).

Finally, the Pearson correlation coefficient indicates the direction and magnitude of the linear association between two numerical variables (Stangor, 2011). In this regard, positive values display a positive linear relationship between variables, while negative values imply an inverse linear relationship.

\section{Results}

\section{Motivational categories}

Both groups of teachers have displayed a similar trend toward autonomous motivation (Table 1) because most of the participants are distributed in high and middle levels of intrinsic motivation and identified regulation. On the Kolmogorov-Smirnov Test's organised output by groups, both clusters rejected the normal distribution $(p<.01)$ in intrinsic motivation and identified regulation. Subsequently, both groups were compared through the Levene's Test and one-way ANOVA. Both 
motivational categories show homogeneity of variance as well as mean equality as $p$-values were greater than the significance level. In light of this, the WTMST Spanish version provides nonparametric data in both groups because the distribution was not normal in each motivational category (Ramsey \& Schafer, 2013).

Table 1. Descriptive Statistics of Motivational Categories, according to the Output by Teacher Groups

\begin{tabular}{lccc}
\hline & \multicolumn{3}{c}{ Distribution (\%) } \\
& High level & Middle level & Low level \\
\hline Teachers who teach compulsory subjects $(\mathrm{n}=611)$ & & & \\
Intrinsic Motivation & 55 & 35 & 10 \\
Identified Regulation & 44 & 42 & 14 \\
\hline Teachers who only teach elective subjects $(\mathrm{n}=119)$ & & & \\
Intrinsic Motivation & 50 & 43 & 7 \\
Identified Regulation & 46 & 36 & 18 \\
\hline
\end{tabular}

Source: Own elaboration

The Mann-Whitney U Test indicated statistically nonsignificant differences between both conglomerates in intrinsic motivation $(p=.39)$ and identified regulation $(p=.49)$ because their $p$ values are higher than the significance level $(d=.01)$. Therefore, it is not relevant to measure the effect size because statistically nonsignificant differences were observed in autonomous motivation between educators who teach compulsory subjects and who only impart elective subjects at school.

\section{Basic psychological needs}

Both groups of educators have displayed the same trend concerning the satisfaction of each basic psychological need (Table 2). On the Kolmogorov-Smirnov Test's organised output by groups, both conglomerates rejected the normal distribution $(p<.01)$ because their $p$-values were lower than the significance level $(d=.01)$. Subsequently, both groups were compared through the Levene's Test, observing in all basic psychological needs a homogeneity of variance due to $p$ values were higher than the significance level $(d=.01)$. Finally, one-way ANOVA indicated mean equality in needs for competence and relatedness because p-values were greater than the significance level $(d=.01)$, while the need for autonomy did not show mean equality $(p<.01)$. In light of this, the BPNS-T provides nonparametric data in both groups because the distribution is not normal in all basic psychological needs (Ramsey \& Schafer, 2013). 
Table 2. Descriptive Statistics of the Satisfaction of Basic Psychological Needs, according to the Output by Teacher Groups

\begin{tabular}{lccc}
\hline & \multicolumn{3}{c}{ Distribution (\%) } \\
& High level & Middle level & Low level \\
\hline Teachers who teach compulsory subjects $(\mathrm{n}=611)$ & & & \\
a. Autonomy & 54 & 42 & 4 \\
b. Competence & 44 & 50 & 6 \\
c. Relatedness & 43 & 52 & 5 \\
\hline Teachers who only impart elective subjects $(\mathrm{n}=119)$ & & & \\
a. Autonomy & 54 & 42 & 4 \\
b. Competence & 44 & 50 & 6 \\
c. Relatedness & 43 & 52 & 5 \\
\hline
\end{tabular}

Source: Own elaboration

The Mann-Whitney U Test indicates a statistically significant difference between both groups in need for autonomy $(p<.01)$, such that the research hypothesis is accepted. However, there are statistically nonsignificant differences between both conglomerates in needs for competence ( $p=$ $.98)$, and relatedness $(p=.44)$ because their $p$-values are greater than the significance level $(\mathrm{d}=$ .01 ). Given these results, it is only relevant to measure the effect size in the need for autonomy. The teacher group explains $1.6 \%$ of the variation in terms of autonomy (Richardson, 2011), as $\eta^{2}$ is equal to .016. Therefore, results demonstrate that differences in teacher autonomy cannot be observed at first sight.

\section{Correlations between motivational categories and basic psychological needs}

In both clusters (Table 3), intrinsic motivation shows a significant positive correlation with the need for relatedness and competence, which are weak and moderate, respectively. Regarding the need for autonomy and its correlation with intrinsic motivation, educators who teach compulsory subjects at school indicates a significant weak positive correlation between variables, whereas the conglomerate of educators who only impart elective subjects at school shows a significant moderate positive correlation between variables. 
Table 3. Coefficients of Determination ( $\mathrm{r}$ of Pearson) between Motivational Categories and Basic Psychological Needs

\begin{tabular}{lccc}
\hline Basic psychological needs & & $\begin{array}{c}\mathrm{r} \text { of Pearson } \\
\text { Competence }\end{array}$ & Relatedness \\
\hline $\begin{array}{l}\text { Teachers who teach compulsory subjects }(\mathrm{n}=611): \\
\text { Motivational Categories }\end{array}$ & Autonomy & & \\
Intrinsic Motivation & $.37^{* *}$ & $.47^{* *}$ & $.26^{* *}$ \\
Identified Regulation & $.37^{* *}$ & $.45^{* *}$ & $.25^{* *}$ \\
\hline Teachers who only impart elective subjects $(\mathrm{n}=119):$ & & & \\
Motivational Categories & & & $.48^{* *}$ \\
Intrinsic Motivation & $.29^{* *}$ & $.35^{* *}$ & $.28^{* *}$ \\
Identified Regulation & & & $.20^{*}$ \\
\hline$* \mathrm{p}<.01, * * \mathrm{p}<.000$ & & & \\
Source: Own elaboration. & & &
\end{tabular}

In terms of identified regulation, the conglomerate of teachers who only impart elective subjects at school indicates significant weak positive correlations with all basic psychological needs. In the case of the group integrated by educators who teach compulsory subjects at school, Pearson's correlation between the identified regulation and the needs for autonomy and relatedness are significant and weakly positive, while the obtained correlation coefficient with the need for competence is significant and moderately positive.

\section{Discussion}

Based on the self-determination continuum (Gagné \& Deci, 2005), teachers' autonomous motivation is affected by each basic psychological need because it is influenced by classroom situations, either positively or negatively (Martínez, Berthel, \& Vergara, 2017; Ryan \& Deci, 2000; Vansteenkiste \& Ryan, 2013). Therefore, the perceived pleasure in the activity plays a determinant role in the mental health of educators (Deci \& Ryan, 2000). These findings are consistent with previous studies (Klassen et al., 2012; Korthagen \& Evelein, 2016; Marshik et al., 2017; Pelletier et al., 2002) as, on the one hand, participant teachers have difficulties for satisfying the need for relatedness, but, on the other hand, they fulfil the need for competence moderately during the interaction with students.

According to SDT, people display optimal engagement and psychological wellbeing when both feelings of competence and relatedness emerge from autonomous behaviours (Ryan, 1993). In this regard, the satisfaction of the needs for competence and relatedness will allow the internalisation of behaviours by its regulation and value, although this internalisation does not ensure autonomous motivation (Gagné \& Deci, 2005). Consequently, the satisfaction of the need for autonomy is crucial in establishing whether the behaviour is autonomous or not because it indicates the degree of identification and assimilation of this behaviour (Reeve et al., 2019; Ryan \& Deci, 2017).

Considering that the satisfaction of the need for autonomy plays a determinant role in autonomous motivation, it is important to emphasise the existence of a difference between both clusters in 
teacher autonomy. This difference should be relevant despite the obtained effect size because, among all basic psychological needs, only the need for autonomy displayed statistically significant differences. Therefore, these findings support the scientific assumption that LOMCE is limiting the teacher autonomy (Gairín, 2015; Prieto \& Villamor, 2018; Sacristán, 2014).

LOMCE is a system based on standardisation (Collet-Sabé, 2017), which is provoking that teachers who only impart elective subjects perceive a greater enjoyment toward pedagogical activity than the other group, although the former is lesser aware that teaching actions have an impact on the mental health of students. Based on these bivariate correlations between the need for autonomy with intrinsic motivation and identified regulation (Riley, 2016), respectively, the present study demonstrates that, in a low-moderate degree, both teacher clusters perceive autonomous motivation because they could regulate behaviours and take decisions autonomously as of a relative pleasure provided by the activity. These findings should be kept under longitudinal observation.

\section{Limitations}

Findings should be cautiously accepted by researchers in some geographical areas from Spain because, even when the sampling unit has statistical representativeness in a national level, it is appropriate to recognise that participant teachers work in primary education schools situated in the Northern and Western autonomous communities. Likewise, the application of BPNS-T also is a limitation because its face validity is put under scrutiny, even when all its factor loadings displayed a practical significance equal to or above +.70 , which allowed to confirm its convergent, discriminant, and construct validities.

\section{Conclusions}

A variety of statistical procedures have shown that educators who teach compulsory subjects indicate a similar low-moderate degree of autonomous motivation than teachers who only impart elective subjects in primary education schools. Nonetheless, it is important to emphasise that the satisfaction of the need for autonomy is crucial in SDT because it indicates the degree of identification and assimilation of autonomous motivation. In this regard, this study demonstrates that LOMCE is limiting the teacher autonomy because, unlike educators who only teach elective subjects, teachers who impart compulsory subjects perceive lesser enjoyment toward teaching activity, even when they are more aware that teaching actions have an impact on the mental health of students.

In conclusion, findings ratify that LOMCE achieves the opposite of the desired effect regarding teacher autonomy because standardised education is inhibiting the capacity for making pedagogical decisions based on the perceived pleasure during lessons. Consequently, LOMCE should be put under scrutiny because its effectiveness for fostering the teacher autonomy is questioned.

\section{Implications}

The incorporation of Basic Psychological Needs Theory is important because, considering that SDT is understood as a macro theory, it can be triangulated with other SDT mini-theories. The 
replication of this study in other educational contexts is possible, as long as contextual conditions are controlled. It is essential to consider that contextual differences could also exist in the Spanish education system, as this study has been circumscribed to primary education. In other words, the study's replication in preschool, secondary, and higher education could reveal other findings. It is also convenient to analyse teacher-student dyadic relationships from the learner autonomy, with the intention of understanding the complexity of classroom situations from a perspective focused on SDT. From a practical standpoint, it is necessary to find a balance between the pedagogy and curriculum, given that a liberating education demands that educators can make decisions autonomously and feel passion during teaching tasks. Finally, it is imperative to delve into teacher beliefs because social imaginary could provide relevant information about teacher autonomy.

\section{Acknowledgement}

The first author expresses his gratitude to the CONICYT PFCHA/DOCTORADO BECAS CHILE/2015 for the granted doctoral scholarship. In addition, this study was supported by the $\mathrm{I}+\mathrm{D}+\mathrm{i}$ State Programme oriented towards Challenges of the Society (grant number EDU201784979-R).

\section{References}

Aldous, C. R. (2019). Unlocking creativity in solving novel mathematics problems: Cognitive and non-cognitive perspectives and approaches. New York, NY: Routledge.

Angel-Alvarado, R., Wilhelmi, M. R., \& Belletich, O. (in press). Validez de constructo: Escala de las Necesidades Psicológicas Básicas para Docentes. Journal for Educators, Teachers and Trainers.

Clayson, D. E. (2017). Student evaluation of teaching and matters of reliability. Assessment \& Evaluation in Higher Education, 43(4), 666-681. doi:10.1080/02602938.2017.1393495

Collet-Sabé, J. (2017). I do not like what I am becoming but...': transforming the identity of head teachers in Catalonia. Journal of Education Policy, 32(2), 141-158. doi:10.1080/02680939.2016.1253873

Deci, E. L. \& Ryan, R. M. (2000). The "What" and "Why" of Goal Pursuits: Human Needs and the Self-Determination of Behavior. Psychological Inquiry, 11(4), 227-268. doi:10.1207/S15327965PLI1104 01

Deci, E. L., \& Ryan, R. M. (2016). Optimizing students' motivation in the Era of testing and pressure: A self-determination theory perspective. In W. Liu, J. Wang, \& R. M. Ryan (Eds.), Building Autonomous Learners (pp. 9-29). Singapore: Springer.

Deci, E. L., Ryan, R. M., Gagné, M., Leone, D., Usunov, J., \& Kornazheva, B. (2001). Need satisfaction, motivation, and well-being in the work organizations of a former eastern bloc country: A cross-cultural study of self-determination. Personality and Social Psychology Bulletin, 27(8), 930-942.

European Union (2013). Ethics for researchers: Facilitating research excellence in FP7. Luxembourg: Publications Office of the European Union.

Fernet, C., Senécal, C., Guay, F., Marsh, F. y Dowson, M. (2008). The work tasks motivation scale for teachers (WTMST). Journal of career assessment, 16(2), 256-279. doi:10.1177/1069072707305764

(c) Psy, Soc, \& Educ, 2020, Vol. 12(1) 
Field, A. (2017). Discovering statistics using IBM SPSS Statistics. London: SAGE.

Fritz, C. O., Morris, P. E., \& Richler, J. J. (2012). Effect size estimates: Current use, calculations, and interpretation. Journal of Experimental Psychology: General, 141(1), 2-18. doi: $10.1037 / \mathrm{a} 0024338$

Gagné, M. (2009). A model of knowledge-sharing motivation. Human Resource Management, 48(4), 571-589. doi:10.1002/hrm.20298

Gagné, M., \& Deci, E. L. (2005). Self-Determination Theory and Work Motivation. Journal of Organizational Behavior, 26, 331-362. doi:10.1002/job.322

Gairín, J. (2015). Autonomy and school management in the Spanish context. Educational, Cultural and Psychological Studies, (11), 103-117. doi:10.7358/ecps-2015-011-gair

Gunnell, K. E., Crocker, P. R. E., Wilson, P. M., Mack, D. E., \& Zumbo, B. D. (2013). Psychological need satisfaction and thwarting: A test of Basic Psychological Needs Theory in physical activity contexts. Psychology of Sport and Exercise, 14, 599-607. doi:10.1016/j.psychsport.2013.03.007

Hair, J., Wolfinbarger, M., Money, A. H., Samouel, P., \& Page, M. J. (2015). Essentials of bussiness research methods. New York, NY: Routledge.

Hinton, P. R. (2014). Statistics explained. New York, NY: Routledge.

Klassen, R. M., Perry, N. E., \& Frenzel, A. C. (2012). Teachers' relatedness with students: An underemphasized component of teachers' basic psychological needs. Journal of Educational Psychology, 104(1), 150-165. doi:10.1037/a0026253

Korthagen, F. A. J., \& Evelein, F. G. (2016). Relations between student teachers' basic needs fulfillment and their teaching behavior. Teaching and Teacher Education, 60, 234-244. doi:10.1016/j.tate.2016.08.021

Marshik, T., Ashton, P. T., \& Algina, J. (2017). Teachers' and students' needs for autonomy, competence, and relatedness as predictors of students' achievement. Social Psychology of Education, 20(1), 39-67. doi:10.1007/s11218-016-9360-z

Martínez, J. D., Berthel, Y., \& Vergara, M. S. (2017). Burnout syndrome in teachers and its relation with the learning of primary students of an official educational institution of Sincelejo (Colombia), 2016. Salud Uninorte, 33(2), 118-128.

Mertler, C. A. (2016). Introduction to educational research. Thousand Oaks, CA: SAGE.

MECD. (2013). Ley Orgánica 8/2013, de 9 de diciembre, para la mejora de la calidad educativa. Boletín Oficial del Estado, 295, 97858-97921. Retrieved from https://www.boe.es/buscar/pdf/2013/BOE-A-2013-12886-consolidado.pdf

Norouzian, R., \& Plonsky, L. (2018). Eta- and partial eta-squared in L2 research: A cautionary review and guide to more appropriate usage. Second Language Research, 34(2), 257-271. doi:10.1177/0267658316684904

Pelletier, L. G., Séguin-Lévesque, C., \& Legault, L. (2002). Pressure from above and pressure from below as determinants of teachers' motivation and teaching behaviors. Journal of Educational Psychology, 94(1), 186-196. doi:10.1037/0022-0663.94.1.186

Prieto, M., \& Villamor, P. (2018). El impacto de una Reforma: Limitación de la autonomía, estrechamiento de la libertad y erosión de la participación. Archivos Analíticos de Políticas Educativas, 26(63), 1-32. doi:10.14507/epaa.26.3255

Ramsey, F. L., \& Schafer, D. W. (2013). The statistical sleuth: a course in methods of data analysis. Boston, MA: Brooks/Cole. 
Reeve, J., Ryan, R. M., \& Deci, E. L. (2018). Sociocultural influences on student motivation as viewed through the lens of Self-Determination Theory. In G. D. Liem \& D. M. Mclnerney (Eds.), Big Theories Revisited 2 (pp. 15-40). Charlotte, NC: Information Age Publishing.

Richardson, J. T. (2011). Eta squared and partial eta squared as measures of effect size in educational research. Educational Research Review, 6(2), 135-147. doi:10.1016/j.edurev.2010.12.001

Riley, G. (2016). The role of self-determination theory and cognitive evaluation theory in home education. Cogent Education, 3(1), 1163651. doi:10.1080/2331186X.2016.1163651

Rosenthal, J. A. (2012). Statistic and data interpretation for social work. New York, NY: Springer.

Ruíz, M. (2015). Soporte de autonomía y motivación en educación: Consecuencias a nivel global y contextual (Doctoral thesis, Universitas Miguel Hernández, Elche, Spain). Retrieved from http://dspace.umh.es/bitstream/11000/1857/1/TD\%20Mar\%c3\%ada\%20Ruiz\%20Quiles.pdf

Ryan, R. M. (1993). Agency and organization: Intrinsic motivation, autonomy and the self in psychological development. In J. Jacobs (Ed.), Nebraska symposium on motivation: Developmental perspectives on motivation (pp. 1-56). Lincoln, NE: University of Nebraska Press.

Ryan, R. M., \& Deci, E. L. (2000). The darker and brighter sides of human existence: Basic psychological needs as a unifying concept. Psychological Inquiry, 11(4), 319-338.

Ryan, R. M., \& Deci, E. L. (2013). Toward a social psychology of assimilation: Self-determination theory in cognitive development and education. In B. W. Sokol, F. M. E. Grouzet, \& U. Müller (Eds.), Self-regulation and autonomy: Social and developmental dimensions of human conduct (pp. 191-207). Cambridge: Cambridge University Press. doi:10.1017/CBO9781139152198.014

Ryan, R. M., \& Deci, E. L. (2017). Self-Determination Theory: Basic psychological needs in motivation, development, and wellness. New York, NY: Guilford Publications. doi:10.7202/1041847ar

Ryan, R. M., \& Deci, E. L. (2019). Brick by brick: The origins, development, and future of selfdetermination theory. Advances in Motivation Science, 6, 111-162). doi:10.1016/bs.adms.2019.01.001

Sacristán, J. G. (2014). La LOMCE. ¿Una ley más de educación? Revista Interuniversitaria de Formación del Profesorado, 81(28.3), 31-44.

Stangor, C. (2011). Research methods for the behavioral sciences. Belmont: Wadsworth.

Van den Broeck, A., Vansteenkiste, M., De Witte, H., Soenens, B., \& Lens, W. (2010). Capturing autonomy, competence, and relatedness at work: Construction and initial validation of the work-related basic need satisfaction scale. Journal of Occupational and Organizational Psychology, 83, 981-1002.

Vansteenkiste, M., \& Ryan, R. M. (2013). On psychological growth and vulnerability: Basic psychological need satisfaction and need frustration as a unifying principle. Journal of Psychotherapy Integration, 23(3), 263-280. doi:10.1037/a0032359 